\title{
METHOD OF FORENSIC ASSESSMENT OF RISK FACTORS OF TREATMENT FAILURE OUTCOMES AS AN ELEMENT OF QUALITY MANAGEMENT OF MEDICAL CARE
}

DOI: 10.36740/WLek202005138

\author{
Vyacheslav K. Sokol', Vira A. Kolesnichenko², Kostyantin M. Sokol' ${ }^{\text {, Vladyslav A. Smiianov }}{ }^{3}$ \\ 'KHARKIV NATIONAL MEDICAL UNIVERSITY, KHARKIV, UKRAINE \\ ${ }^{2}$ KHARKIV NATIONAL UNIVERSITY NAMED AFTER V.N. KARAZIN, KHARKIV, UKRAINE \\ 'SUMYY STATE UNIVERSITY, SUMY, UKRAINE
}

\begin{abstract}
The aim: The aim of this research was to study causes of the development of adverse outcomes in isolated femoral diaphyseal fractures.

Materials and methods: A retrospective analysis of the protocols of clinical and radiological examination of 21 patients was performed. Based on the initial expert assessment, these patients have not been established the severity of injuries due to the development of complications in the postoperative period.

Conclusions: Patient-dependent, implant-dependent, and surgery-dependent causes that caused a violation of the stability of osteosynthesis (95.2\%) were identified. This led to a secondary displacement of bone fragments (71.4\%), delayed fracture consolidation (61.9\%), the formation of pseudarthrosis (38.1\%), the development of post-traumatic osteomyelitis (14,3), migration of screws from the osseous plate (47.6\%), and the development of post-traumatic contracture of the knee joint (81.0\%).
\end{abstract}

KEY WORDS: diaphyseal femoral fracture, surgical treatment, perioperative risk factors, unsatisfactory outcomes

Wiad Lek. 2020;73(5):1041-1047

\section{INTRODUCTION}

The optimal level of public health is one of the most important conditions for social and economic development, national security of state. One of the main elements of public health management is to improve methods for assessing and predicting public health risks. This complex versatile problem demands multitask and diverse methodological solutions [1]. A mandatory component of such a methodology is the assessment, forecast and management of risk factors that have the most significant impact on the health status of population.

One of the priority areas of the WHO "Health 2020: a European policy" is "providing high-quality medical care and improving health outcomes ... using science-based methods" [2]. In the supervision of the medical care quality, one of the most important elements is the scientific forecasting and prevention of treatment defects that lead to long-term incapacity for work and/or disability of patients.

In forensic medical examinations, signs of inadequate scheduled medical care are established in an average of $46.7 \%$ of cases [3]. In emergency clinical situations, the proportion of defects in diagnosis and treatment increases significantly, reaching $90.5 \%$ in cases of road traffic accidents. [4].

Fractures of the femur that were not complicated by damage to the main vessels and nerves, are assessed as bodily injuries of moderate gravity. However, in the process of fracture's fusion, regardless of the treatment method (immobilization or various types of osteosynthesis), there is a complications' development. The most common complication is a defect of reparative processes in the fracture zone (delayed consolidation, non-fusion of bone fragments, pseudarthrosis), as well as persistent contractures of adjacent joints $[5,6]$. The development of complications in the post-traumatic period usually worsens the outcome of the injury and, according to the "Rules of Forensic Medical Determination of the Severity of Bodily Injuries", often leads to grave consequences, as a result of harm to health.

The frequency and features of complications that develop during the treatment of femoral fractures had been already studied. Errors and complications in the treatment of hip fractures in victims with polytrauma $[7,8]$, in patients with fractures of particular segments of the femur $[9,10]$ had been studied as well.

\section{THE AIM}

The aim of this research was to study causes of the development of adverse outcomes in isolated femoral diaphyseal fractures.

\section{MATERIALS AND METHODS}

Materials and methods of study were retrospective analysis of protocols of clinical and radiological examination of 21 
patients with adverse outcomes of an isolated femur shaft fractures, which, according to the results of the initial expert assessment, did not establish the severity of bodily injuries due to the development of complications in the postoperative period. All patients were observed at the SI "M.I. Sitenko Institute of Spine and Joint Pathology, NAMS of Ukraine" in 2014 - 2019.

Criteria for inclusion in the study were adverse outcomes of a fracture of the femur diaphysis (non-fusion of bone fragments, pseudarthrosis, post-traumatic shortening and/ or deformation of the femur, post-traumatic contracture of the knee joint). Criteria for exclusion from the study were hip fractures with fractures of several bones, combined injuries, fractures of the proximal or distal femur epimetaphysis.

All patients underwent surgical treatment using various methods of internal fixation of fragments of the femur using metal structures. When studying the features of the adverse results of femoral diaphysis fractures, an EFORT classification was used, according to which patient-dependent, implant-dependent and surgery-dependent causes and/ or risk factors for complications after surgical treatment of orthopedic and traumatic patients were distinguished [11].

The Quetelet body mass index was calculated by the formula ' $\mathrm{m} / \mathrm{h} 2$ ', where $\mathrm{m}$ - body weight in kilograms, $\mathrm{h}$ height in meters.

In the statistical processing of the material methods of descriptive statistics were used.

\section{REVIEW AND DISCUSSION}

Among the patients included in this study, men predominated $(76.2 \%)$. All patients were of working age. The main cause of fractures in this category of patients were traffic accidents ( $90.4 \%$ of cases); closed femoral diaphysis frac-

Table I. Distribution of patients by gender, age and some features of femoral diaphysis fractures

\begin{tabular}{|c|c|}
\hline Options & N (\%) \\
\hline \multicolumn{2}{|l|}{ Sex } \\
\hline Male & $16(76.1)$ \\
\hline Female & $5(23.8)$ \\
\hline \multicolumn{2}{|c|}{ Average age $32.12 \pm 14.33$ years old $(18-48$ years old } \\
\hline \multicolumn{2}{|c|}{ Cause of fracture } \\
\hline Traffic accident & $19(90.4)$ \\
\hline Fall from height & $1(4.8)$ \\
\hline Gunshot wound & $1(4.8)$ \\
\hline \multicolumn{2}{|c|}{ Fracture localization } \\
\hline Top 1/3 & $3(14.3)$ \\
\hline Middle $1 / 3$ & $16(76.1)$ \\
\hline Bottom 1/3 & $2(9.6)$ \\
\hline \multicolumn{2}{|c|}{ Type of fracture } \\
\hline Open & $3(14.3)$ \\
\hline Closed & $18(85.7)$ \\
\hline
\end{tabular}

tures $(85.7 \%)$ in the middle third $(76.1 \%)$ predominated. Only 2 primary open fractures were revealed (gunshot and due to a fall from a height) and 1 - secondary open as a result of an accident (Table I).

It should be noted that in no patient before surgery, osteoporosis or cases of hormone therapy were detected, which are significant risk factors for delayed fracture consolidation.

Study of primary radiographs made it possible to establish that only one patient with an open gunshot hip fracture in the middle third, by features of bone-traumatic injuries (defect of the femoral diaphysis up to $4 \mathrm{~cm}$ long) initially had a complicated and prolonged postoperative period with delayed fracture consolidation, the need for recovery the anatomical length of the damaged segment, a high risk of developing post-traumatic osteomyelitis. In all other cases, features of fracture did not make effect the development of postoperative complications with a worsening treatment outcome.

When studying the causes of unsatisfactory results of surgical treatment of diaphyseal fractures of the femur, the following patient-related, surgery-related and implant-related causes were identified (Table II).

Among the patient-dependent causes, the most significant risk factors for complications after an open reposition of a femoral diaphysis fracture were a combination of obesity, arthrosis of adjacent (hip and knee) joints in $12(57.1 \%)$ patients. Even with initial changes ( ${ }^{\text {st }}$ degree obesity, $I^{\text {st }}$ degree coxarthrosis, ${ }^{\text {st }}$ degree gonarthrosis), inadequate motor regime in the form of physical inactivity in the postoperative period potentiated the development of persistent restriction of movements in the knee joint with the formation of extensor contracture, relative (functional) shortening of the lower limb, and violation of the motor stereotype in $4(19.0 \%)$ patients. Also, in these patients, there was a significant reduction in the dosed load on the damaged lower limb in early stages of primary fibrocartilage callus formation in the fracture zone, which was accompanied by inhibition of reparative regeneration processes with a delayed formation of secondary fibrocartilage callus. Violation of the motor regime with excessive axial load on the operated limb during the rehabilitation period was also accompanied by delayed consolidation in the fracture zone (another 4 (19.0\%) observations) - see tables II, III.

The study of implant-dependent causes showed that in all cases of the development of postoperative complications, a mismatch was found between the standard size of the metal structure used for immersion osteosynthesis and the anatomical sizes of fractured femur's fragments. Migration of a short intramedullary rod was observed in one $(4.8 \%)$ case. In another case $(4.8 \%)$ of blocked intramedullary osteosynthesis of a hip diaphysis fracture in the lower third, the use of a narrow intramedullary nail and a short distal blocked nail was accompanied by migration of the blocked nail and rod's breakage at the level of the femoral fracture, secondary displacement of bone fragments and the absence of fracture consolidation signs. 
Table II. The reasons for the unsatisfactory results of the surgical treatment of femoral diaphysis fractures

\begin{tabular}{|c|c|c|}
\hline No. & The reasons for the unsatisfactory results of the surgical treatment of femoral diaphysis fractures & $\mathrm{N}(\%)$ \\
\hline \multicolumn{3}{|c|}{ Patient-related causes } \\
\hline 1 & Alcohol intoxication at the time of injury (light degree) & $3(14.3)$ \\
\hline 2 & Obesity (Quetelet index $\geq 31$ ) & $8(38.1)$ \\
\hline 3 & History of coxarthrosis (|lt degree) & $2(9.6)$ \\
\hline 4 & History of gonarthrosis (Ist degree) & $6(28.6)$ \\
\hline 5 & Violation of the orthopedic regime in the immediate postoperative period & $4(19.0)$ \\
\hline 6 & Violation of the orthopedic regime during the rehabilitation period & $4(19.0)$ \\
\hline \multicolumn{3}{|c|}{ Implant-related causes } \\
\hline 7 & Inconsistency of the length of the intramedullary shaft and the length of the bone marrow canal of the femur & $1(4,8)$ \\
\hline 8 & Inconsistency between the diameter of the intramedullary shaft and the width of the bone marrow canal of the femur & $1(4,8)$ \\
\hline 9 & $\begin{array}{l}\text { Discrepancy between the length of the distal blocking nail and the anteroposterior diameter of the distal } \\
\text { femur metaphysis }\end{array}$ & $2(9,6)$ \\
\hline 10 & Inconsistency of the length of cortical screws with the diameter of the femoral diaphysis & $9(42,9)$ \\
\hline \multicolumn{3}{|c|}{ Surgeon-related causes } \\
\hline 11 & Violation of $x$-ray technology & $3(14,3)$ \\
\hline 12 & Violation of the terms of postoperative $x$-ray monitoring & $5(23,8)$ \\
\hline 13 & Violation of the terms of postoperative antibiotic therapy & $3(14,3)$ \\
\hline 14 & Untreated intraoperative displacement of femur fragments & $5(23,8)$ \\
\hline
\end{tabular}

Table III. Types of adverse outcomes of osteosynthesis of diaphyseal fractures of the femur

\begin{tabular}{ccc} 
No. & Types of adverse outcomes of osteosynthesis of diaphyseal fractures of the femur & $\mathbf{n}(\%)$ \\
\hline 1 & Fracture of the intramedullary nail & $1(4,8)$ \\
\hline 2 & Intramedullary rod migration & $1(4,8)$ \\
\hline 3 & Migration of a distal blocked nail from an intramedullary nail & $1(4,8)$ \\
\hline 4 & Migration of screws from the bony plate & $10(47,6)$ \\
\hline 5 & Secondary displacement of bone fragments of the femur & $10(47,6)$ \\
\hline 6 & Suppuration of a postoperative wound & $5(23,8)$ \\
\hline 7 & The development of post-traumatic osteomyelitis & $3(14,3)$ \\
\hline 8 & The development of post-traumatic contracture of the knee & $17(81,0)$ \\
\hline 9 & Slow hip fracture consolidation & $13(61,9)$ \\
\hline 10 & The formation of pseudarthrosis of the femur & $8(38,1)$ \\
\hline 11 & Post-traumatic femoral deformity & $15(71,4)$ \\
\hline
\end{tabular}

Unstable fracture osteosynthesis in this patient potentiated the development of chronic post-traumatic osteomyelitis (Fig. 1, a, b, Tables II, III).

The use of short cortical screws for bone osteosynthesis, especially in conditions of comminuted fracture of the femoral diaphysis, caused the migration of screws with impaired stability of bone fragments fixation, delayed fracture consolidation $(\mathrm{n}=4 ; 19.0 \%)$, and the formation of a false joint $(\mathrm{n}=5 ; 23.8 \%)$.

Surgically dependent causes that could lead to the development of complications of osteosynthesis of diaphyseal hip fractures were noted throughout the perioperative period, but mainly after surgery. Most often, there was a violation of the terms of postoperative $\mathrm{x}$-ray monitoring of the operated segment and unrepaired intraoperative displacement of the fragments of the femur $(n=5 ; 23.8 \%)$. Violation of the technology of $\mathrm{x}$-ray diagnostics by: performing $\mathrm{x}$-ray of the femur only in the lateral projection, as well as only in the area of the diaphyseal fracture without adjacent joints, was noted in $2(9.6 \%)$ and 1 (4.8\%) cases, respectively.

In one of the clinical cases with osteosynthesis of comminuted hip fracture, a violation of the $\mathrm{x}$-ray diagnostic technology (performing only one projection of the damaged segment) did not allow intraoperative visualize if there was a completely insufficient fixation of femur fragments (Fig. 2 A), which was revealed only after 4 months after open reduction (Fig. 2, B, C) and led to delayed consolidation of the fracture with a tendency to false joint formation and post-traumatic deformation of the femoral diaphysis (Fig. 2, D). 


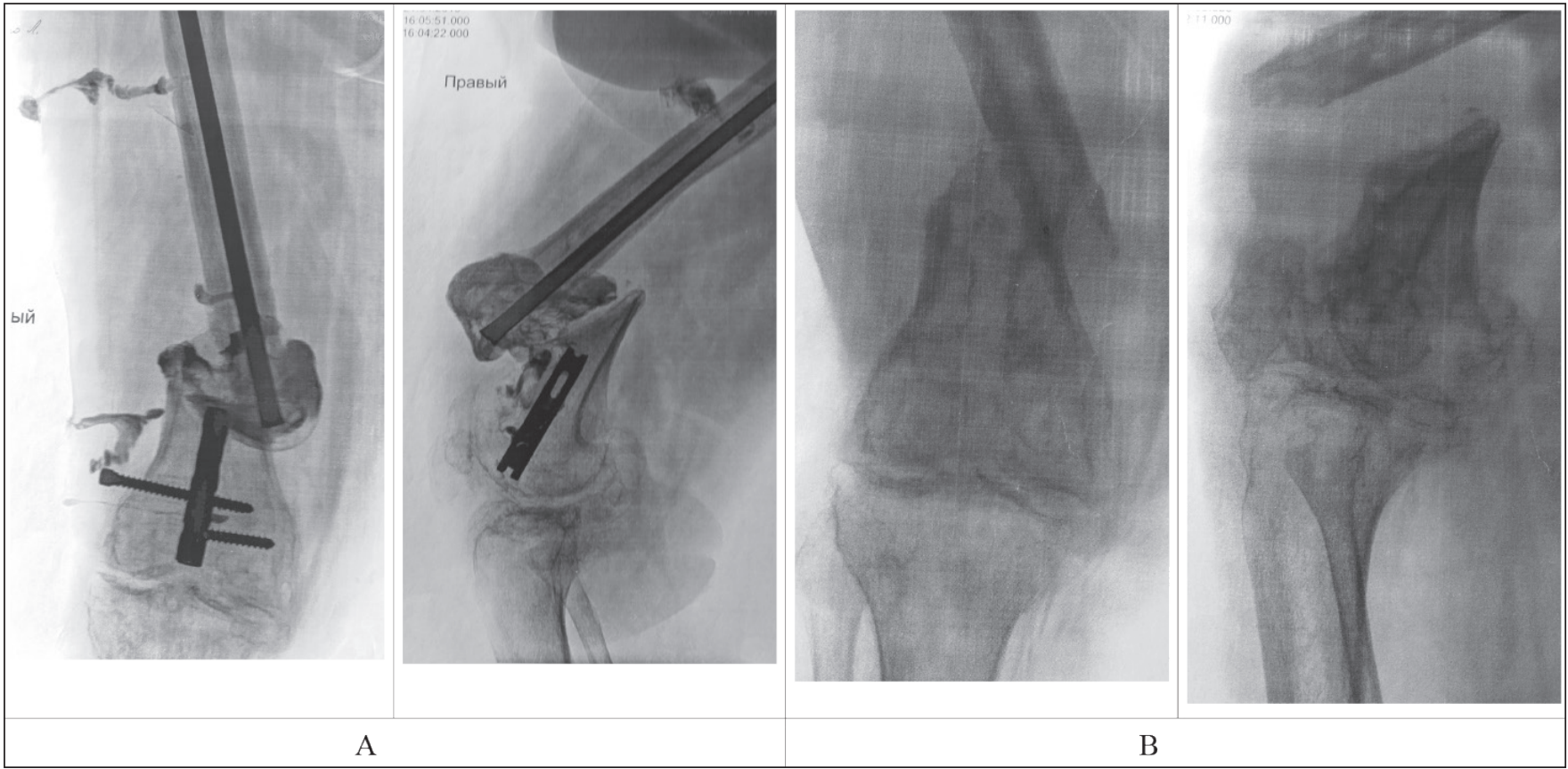

Fig. 1. A - fistulograms of a femoral fracture in the lower third, during surgical treatment, with the development of fistulous type of post-traumatic osteomyelitis: breakage of the intramedullary blocking rod, migration of the upper distal screw, fistulous passages filled with contrast; B - the absence of reparative fusion in the fracture area after removal of the intramedullary shaft.

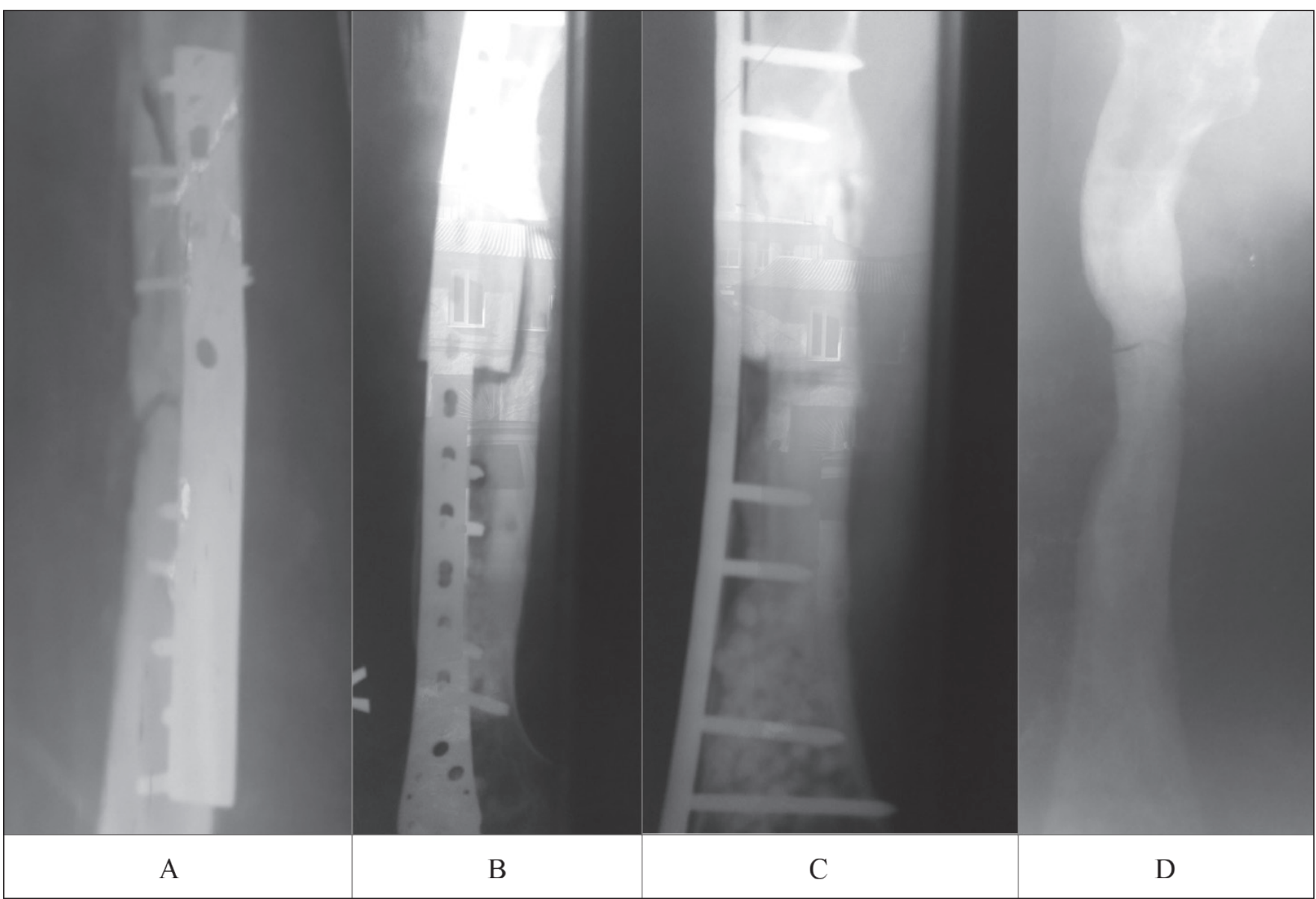

Fig. 2. radiographs of a comminuted femoral fracture in the middle third during surgical treatment: A- (on the day of the injury, anteroposteriorview) - insufficient (short) fixation of the proximal fragment, diastasis between the proximal, distal and comminuted fragments; B (anteroposterior view), C (lateral view) - in 4 months after the operation, the osteoporosis zone is visualized around the distal screws (B), diastasis between the distal fragment and the osseous plate (C); $D$ (anteroposterior view) 6 months after the injury - removal of the osseous plate; diastasis between the proximal and distal fragments of the femur is observed. 
In Table III (14.3\%) patients, antibiotic therapy was started only after the development of inflammatory changes in the postoperative wound area.

Femur diaphysis fractures are one of the most common skeleton injuries. The total frequency of this injury, taking into account femoral diaphysis fractures during multiple and combined injuries, has been kept at a practically constant level in recent years: for 1 year, the average number was 20.8 per 100,000 adult population in 2018 [12] and 21 per 100,000 adult population in 2013 [13]. The frequency of isolated fractures of the femoral diaphysis within 1 year reaches an average of 10 per 100,000 adult population [14]. Since the femur is the largest in the skeleton, surrounded by the largest muscle mass, and one of the main supporting bones of the lower limb, isolated hip fractures are accompanied by significant blood loss, the development of traumatic shock, and lead to long-term disability regardless of the level of (high or low) kinetic energy traumatic factor [15].

The mechanism and location of the femoral fracture depends on the age of the victims. At the age of 40-45 years, femoral diaphysis fractures usually occur due to high-energy injuries [16]; the most common type of injury is an accident (up to 75\%), a fall from a height (up to 7.3 - $10.0 \%)$, gunshot injuries $(2.3-4.5 \%)[17,18]$. In older people, the proximal part of the femur is mainly damaged due to low-energy injuries, more often as a result of a fall from a small height [19].

Despite the advantages of surgical treatment of mechanical damage to the skeleton (stable fixation of the damaged segment, early motor activation of patients and early initiation of active rehabilitation treatment), the use of open fixation for fractures of the femur is still a matter of discussion $[20,21]$. Such a restrained approach to choosing a surgical method of treatment is associated with a rather high frequency of postoperative complications, especially provided that such complications in patients with a fracture of the femur are more common and more difficult than with fractures of long tubular bones of a different location [22], which not only leads to lengthening of the disability period of the patients, but also - to their disability [23].

It should be noted that the internal fixing metal structures, which are used in the surgical treatment of skeleton bone fractures, during their usage can be damaged by loads exceeding the strength of both the device structure itself and the bone to which they are fixed [24, 25]. This problem can be: 1) iatrogenic (the result of a violation of preoperative preparation, osteosynthesis technology or postoperative management) $[26,27] ; 2)$ associated with the patient, when, due to a violation of limits regime concerning the operated limb loads, these loads exceeded the durability of the implant or bone [28];3) due to the manifestation of a latent structural defect, which can lead to a fixator fracture in the absence of obvious external causes and full compliance with both surgical technology and recommendations for the postoperative regime $[29,30]$.

The most common cause of complications of submersible osteosynthesis of fractures of long tubular bones is a violation of the technology of internal fixation of bone fragments [31-
33]. The first step to successful consolidation of the fracture is an open reduction with the restoration of the anatomical relationship in the damaged bone $[31,34,35]$; in the process of open reduction, it is necessary to avoid extensive skeletalization of fragments $[36,37]$, which allows to save the maximum possible vascularization of the fracture zone. Important aspects of the prevention of complications are preoperative planning with indications for the method of internal fixation, the correct operation with the optimal use of fixing structures [38], long and short screws depending on the fracture type (comminuted, non-fragmented) and fracture location [39, 40], an early active development of movements in adjacent joints and a dosed load on the operated limb.

A potential limitation of our work was the relatively small number of observations $(\mathrm{n}=21 ; 100 \%)$ of adverse results in surgical treatment of femur diaphysis' isolated fractures. It should be noted that at present, according to literature and our study results, the main cause of femoral fractures are traffic accidents. At the same time, polytrauma usually develops, whereas isolated fractures of skeleton bones are much less common.

In addition, when identifying risk factors for adverse surgical treatment outcomes, cases with closed $(\mathrm{n}=18 ; 85.7 \%)$ and open $(\mathrm{n}=3 ; 14.3 \%)$ femoral diaphysis fractures were combined into one group. Abovementioned restrictions could affect the frequency of studied risk factors' occurrence. Considering this, we applied this research design in order to show: that adverse outcomes of patient treatment do not appear only as a result of iatrogenic defects in diagnosis and treatment; patient-dependent factors could also potentiate such outcomes. To more accurately identify the causes of the development of adverse outcomes in surgical treatment of femoral diaphysis' isolated fractures, further studies with an increased number of observations and their division into separate groups of closed and open injuries are required.

\section{CONCLUSIONS}

In our study, unstable fixation of a diaphyseal femoral fracture, due to various reasons, was detected in 20 (95.2\%) cases. This led to a significant restriction of the motor regime in the postoperative period and potentiated the development of knee joint contractures in 17 (81.0\%) patients and impaired consolidation in all cases with a slower fracture fusion in $13(61.9 \%)$ patients, and the formation of a false joint in $8(38.1 \%)$ patients.

It should be noted that, in our study, the patient-dependent risk factors for adverse outcomes of surgical treatment of isolated femoral diaphysis fractures, such as: obesity (38.1\%), coxarthrosis (9.6\%) and gonarthrosis (28.6\%) were identified. The decrease in frequency of these risk factors is associated not only with medical care quality supervision, but also, in a more general sense, with the management of public health. Decrease of the number of obesity and non-infectious degenerative joint diseases will help to increase the level of public health (and individual health as its component), improve the quality of medical care and treatment results. 
A forensic medical examination of such outcomes of diaphyseal fractures of the femur are assessed as a serious injury to health. At the same time, a thorough study of the causes of the unfavorable outcome of this fracture with a differentiated approach and taking into account the influence of patient-related, implant-related and surgery-related factors on given treatment outcome is necessary.

\section{REFERENCES}

1. Kliuchenovich V.I. Obshchestvennoe zdorovue: kontseptualnie podchodi pri cozdaniy modeli upravleniua [Public health: conceptual approaches to creating a management model]. Med news. 2005; 3:65-70. (Ru)

2. Health 2020: A European Policy Framework and Strategy for the 21st Century. Copenhagen:WHO Regional Office for Europe UN City. 2015; 224.

3. Sergeev Yu.D., Erofeev S.V. Neblagopriyatniy ischod okazaniya meditsinskoi pomoshchi [Adverse outcomes of medical care] Moscow: Medicine. 2001; 288. (Ru)

4. Novoselov V.P., Kanunnikova L.V. Kompleksnaua otsenka nenadlezhashcheho okazaniua meditsinskoi pomoshchi [Comprehensive assessment of inadequate medical care]. Probl expertise med. 2005; 4:46. (Ru)

5. Deepak C.D., Chethan B.A. A study of functional outcome of femoral diaphyseal fractures by closed reduction and internal fixation using intramedullary interlocking nail in adults. Int J Orthop Sci. 2019; 5(1):132-138. D0l: https://doi.org/10.22271/ortho.2019.v5.i1c.25.

6. McLaughlin M.A., Orosz G.M., Magaziner J. et al. Preoperative status and risk of complications in patients with hip fracture. J General Int Med. 2006; 21(3):219-225.

7. Giannoudis P.V. Surgical priorities in damage control in polytrauma. J Bone Surg (Br). 2003; 85:478-483.

8. Plotnikov I.V., Bondarenko A.V. Oslozhneniya intramedulluarnogo blokiruemogo osteosynteza diafizarnyh perelomov bedra u patsientov s polytravmoy [Complications of intramedular lockable osteosynthesis of femur shaft fracture in patients with politrauma]. New med technologies. 2012; 1:15 - 37. (Ru)

9. Koyuncu S., Altay T., Kayal C. et al. Mechanical failures after fixation with proximal femoral nail and risk factors. Clin intervent aging. 2015; 10:1959-1965.

10. Ehlinger M., Adam P., Arlettaz Y. et al. Minimally-invasive fixation of distal extra-articular femur fractures with locking plates: Limitations and failures. Orthop Traum: Surg Res. 2015; 97:674-680.

11. Bentley G., (ed.). European Surgical Orthopaedics and Traumatology. The EFORT Textbook: Springer. 2014.

12. Enninghorst N., McDougall D., Evans J.A. et al. Population-based epidemiology of femur shaft fractures. Trauma Acute Care Surg. 2013; 74(6):1516-520. doi: 10.1097/TA.0b013e31828c3dc9.

13. Enninghorst N., McDougall D., Sisak K. et al. The epidemiology of femoral shaft fractures in an inclusive trauma system. Orthop Proceed. 2018; 94-B. Available from: https://online.boneandjoint.org.uk/doi/ abs/10.1302/1358-992X.94BSUPP_XLI.AOA-NZOA2011-132.

14. Asplund C.A., Mezzanotte T.J. Midshaft femur fractures in adults. UpToDay. 2019. Available from: https://www.uptodate.com/contents/ midshaft-femur-fractures-in-adults\#H14.

15. Deepak M.K., Rajamanya K.A., Gandhi P.R. et al. Functional outcome of diaphyseal fractures of femur managed by closed intramedullary interlocking nailing in adults. Ann African Med. 2012; 11(1):52-57. D0I: 10.4103/1596-3519.91025
16. Adnan R.M., Zia M.I., Amin J.I. Frequency of femoral fractures; comparison in patients less than and more than 40 years of age. Prof Med J. 2012; 19:11.

17. Zhang Y. Clinical epidemiology of orthopaedic trauma (2nd ed.). Stuttgard, New York: Thieme. 2016.

18. Anderson S.R., Nelson S.C., Morrison M.J. Unstable pediatric femur fractures: combined intramedullary flexible nails and external fixation. J Orthop Case Report. 2017; 7:32.

19. Fajar J.K., Taufan T., Syarif M. et al. Hip geometry and femoral neck fractures: A meta-analysis (review article). J Orthop Translation. 2018; 13:1-6.

20. Medda S., Halvorson J. Diaphyseal femur fractures. StatPearls Publishing LLC. 2019.

21. Augatab P., Rüdenabc C. Evolution of fracture treatment with bone plates. Injury. 2018; 49(1):2-7. doi: https://doi.org/10.1016/S00201383(18)30294-8

22. Sultanbaev T.Tz, Alchogaev S.S., Tusupov D.M. Oshibki oslozhneniya pri lechenyi perelomov bedra [Errors and complications in the treatment of hip fractures]. Vestnik KazNMU. 2019; 3(1):309-311. (Ru)

23. Korzh N.A., Gerasimenko S.I., Klimovitskyi V.G. et al. Rasprostranennost' perelomov koster i rezul'taty ikh lecheniya v Ukraine (klinikoepidemiologicheskoye issledovaniye) [The prevalence of bone fractures and the results of their treatment in the Ukraine (clinical and epidemiological study)]. Med news. 2011; 7:37-44. (Ru)

24. Bel J.C. Pitfalls and limits of locking plates. Orthop Traum: Surg Res. 2019; 105 (1):103-109.

25. Ahtyamov I.F., Shakirov F.V., Gatina E.B. et al., Manirambona, ZhK, \& Aliev El. Morfologicheskoye issledovaniye lokal'nogo vliyaniya implantatov s pokrytiyami na osnove sverkhtverdykh soyedineniĭ na kostnuyu tkan' v usloviyakh indutsirovannoi travmy [Morphological study of the local effect of implants with coatings based on superhard compounds on bone tissue under conditions of induced trauma]. J Clin Experim Orthop named G.A. llizarov. 2015; 1:65-70. (Ru)

26. Volotovskyi P.A., Sytnik A.A., Beletskyi A.V. Infektsionnyye oslozhneniya posle osteosinteza dlinnykh trubchatykh kostey: etiologiya, klassifikatsiya i diagnostika. [Infectious complications after osteosynthesis of long tubular bones: etiology, classification and diagnosis]. Military med. 2018; 1:83-89. (Ru)

27. Elmi A., Rohani A.R., Tabrizi A. et al. Esmaili, SM. Comparison of outcome of femoral shaft fracture fixation with intramedullary nail in elderly patient and patients younger than 60 years old. Arch Bone JSurg. 2014; 2(2):103-105.

28. Kobbe P., Klemm R., Reilmann H. et al. Less invasive stabilisation system (LISS) for the treatment of periprosthetic femoral fractures: a 3-year follow-up. Injury. 2008; 39:472-479.

29. Li Y.L., Guo W.P., Jiang W.T. et al. Biomechanical study on the influence of shaping amplitude on material strenght of titanium implant. Applied Mech Material. 2013; 275:38-43. doi: https://doi.org/10.4028/www. scientific.net/AMM.275-277.38

30. Hung L.W., Chao C.K., Huang J.R. et al. Screw head plugs increase the fatigue strength of stainless steel, but not of titanium, locking plates. Bone J Res. 2018; 7(12):629-635. doi: 10.1302/2046-3758.712.BJR$2018-0083 . R 1$

31. Sadic S., Custovic S., Smajic N. et al. Complications and functional recovery in treatment of femoral shaft fractures with unreamed intramedullary nailing. Med Arch. 2014; 68(1):30-33.

32. Gueorguieva B., Lenzb M. Why and how do locking plates fail? Injury. 49(1):56-60. doi: https://doi.org/10.1016/50020-1383(18)30305-X. 
33. Ehlinger M., Adam P., Di Marco A. et al. Periprosthetic femoral fractures treated by locked plating: Feasibility assessment of the miniinvasivesurgical option. A prospective series of 36 fractures. Orthop Traum: Surg Res. 2011; 97(6):622-628.

34. Akinoola L., Orekha 0., Odunsi A. Open intramedullary nailing of neglected femoral shaft fractures: indications and outcome. Acta Orthop Belgica. 2011; 77:73-77.

35. AlTurki A.A., AlAqeely K.S., AlMugren T.S. et al. Analysis of femoral fracture post motor vehicle accidents. Saudi Med J. 2019;40(1):41-44. doi: 10.15537/smj.2019.1.21547

36. Berry D.J. Management of periprosthetic fractures: the hip. J Arthroplasty. 2002; 17:11-13.

37. Xing W., Pan Z., Sun L. et al. Sliding bone graft combined with double locking plate fixation for the treatment of femoral shaft nonunion. J Int Med Res. 2019; 47(5):2034-2044. D0I: 10.1177/0300060519835334.

38. Dim E.M., Ugwoegbulem 0.A., Ugbeye M.E. Adult traumatic femoral shaft fractures. A review of the literature. Ibom Med J. 2012;5(1):26-38.

39. Bottlang M., Doornink J., Byrd G.D. et al. A nonlocking end screw can decrease fracture risk caused by locked plating in the osteoporotic diaphysis. J Bone Joint Surg (Am.). 2009; 9:620-627.

40. Ehlinger M., Ducrot G., Adam P. et al. Distal femur fractures. Surgical techniques and a review of the literature. Orthop Traum: Surg Res. 2013; 99:353-360.
This work is a fragment of research work of the Department of Forensic Medicine, Medical Law named after hon. prof. MS Bokarius Kharkiv National Medical University "Forensic substantiation of morpho-clinical criteria for expert assessment of bodily injuries, determination of limitation period and cause of death", state registration number $0115 U 000229$.

\section{ORCID and contributionship:}

Vyacheslav K. Sokol - 0000-0002-8892-1765 A,B,D,F

Vira A. Kolesnichenko - 0000-0003-0503-9732 B,D,E,F

Kostyantin M. Sokol - 0000-0001-6849-579X C,D,F

Vladyslav A. Smiianov - 0000-0002-4240-5968 ${ }^{\text {A,E }}$

\section{Conflict of interest:}

The Authors declare no conflict of interest.

\section{CORRESPONDING AUTHOR}

Vira A. Kolesnichenko

Klochkovskaya str., app. 90, 186 «b», Kharkiv, Ukraine, 61145

tel: +380661418991

e-mail:28111957vk@gmail.com

Received: 26.01 .2020

Accepted: 30.03 .2020

A - Work concept and design, B - Data collection and analysis, C - Responsibility for statistical analysis,

D-Writing the article, $\mathbf{E}$ - Critical review, $\mathbf{F}$ - Final approval of the article 